\title{
TESTING SOCIAL DISORGANIZATION THEORY FOR THE CAUSES OF INDEX (MAJOR) CRIME INCIDENCE AMONG TURKISH JUVENILES
}

\author{
TÜRK GENÇLERİ ARASINDAKİ AĞIR SUÇLARIN SEBEPLERININ TESPITTI İÇIN \\ SOSYAL DÜZENSIZLLIK TEORISSININ TESTI
}

Taner ÇAM ${ }^{1}$

\begin{abstract}
Testing social disorganization theory for the causes of index (major) crime incidence among Turkish juveniles is the subject of this study. Delinquency rates are quite high and it is an important problem for every society. It is needed to know the causes of delinquency to find appropriate solution ways and to decrease the delinquency rate. Thus, this article was prepared by utilizing data belongs to 205 incarcerated juveniles from different juvenile correction facilities in Turkey in 2007. Binary Logistic regression was used to analyze the data. Multivariate analysis indicates that education and living in urban areas have significant effect on the probability of index crime incidence. The implications of the findings were discussed in the paper.
\end{abstract}

Key Words: Juvenile delinquency, index crime, education, welfare, unemployment, urbanization, and family disruption.

\section{$\ddot{\mathbf{O} z}$}

Çalışmanın konusu, Türk gençleri arasındaki indeks (ağır) suçların sebeplerinin tespiti için sosyal düzensizlik teorisinin testidir. Çocuk suçluluğu oranları oldukça yüksektir ve bu durum her toplum için önemli bir problemdir. Uygun çözüm yolları bulmak ve çocuklar tarafından işlenilen suçların oranlarını düşürmek için suçun sebeplerinin bilinmesi gerekir. Bu yüzden, bu makale, 2007 yılında, Türkiye'deki farklı cezaevlerinde bulunan 205 tutuklu gence ait veriler kullanılarak hazırlanmıştır. Verilerin analizi için ikili (binary) lojistik regresyon yöntemi kullanılmıştır. Çok değişkenli regresyon analizi, eğitimin düzeyinin ve şehir merkezlerinde yaşıyor olmanın, ağır suçların işlenme ihtimali üzerinde anlamlı bir etkisinin olduğunu gösteriyor. Bulguların ne anlama geldiği makalede tartışılmıştır.

Anahtar Kelimeler: Çocuk suçluluğu, ağır suç, eğitim, refah, işsizlik, kentleşme ve aile parçalanması.

\footnotetext{
${ }^{1}$ Dr., Öğretim Görevlisi, A. Gaffar PMYO, Diyarbakır, taner.cam@gmail.com
} 


\section{Introduction}

Almost $16 \%$ of total arrest was juveniles in the US in 2000. (Shoemaker \& Wolfe, 2005). Similarly, according to FBI uniform crime reports, juvenile arrest rate was about $15 \%$ of total arrest rate in 2003 (Bartollas, 2006). Similar to United States, these rates are increasing in Turkey due to different factors. According to uniform records, while there were 2017 incarcerated delinquents in 2002, the number of them was 2784 as of June 2007 (www.adli-sicil.gov.tr). Furthermore, uniform delinquent records indicated that the rate of juvenile suspects caught by police increased about 30\% between 2001 and 2005 (www.tuik.gov.tr).

The criminal behaviors committed by juveniles diverse. That is, it includes all kinds of activity accepted as crime by juveniles. In order to understand crimes committed by juveniles, it is needed to define delinquency and status offenses. Delinquency and status offenses are two different things. Status offenses are the crimes applied only to juveniles (Bynum \& Thompson, 2002; Shoemaker, 2005; Shoemaker \& Wolfe, 2005) such as repeatedly refuse to obey parents, do not attend school or run away from home. All kinds of illegal acts, both criminal and status offenses, committed by youth under the age of 18 are delinquent behavior, and the youths committing this kind of acts are called juvenile delinquents. As it is for crimes, delinquent acts are handled into two different categories. These are index offenses and non-index offenses. Index offenses are the part of this study; thus, it is need to know what index crimes are. FBI's uniform crime reports measure eight index or Part I criminal offenses as murder, aggravated assault, rape, robbery, burglary, motor vehicle theft, larceny theft, and arson. These are serious crimes (Bynum \& Thompson, 2002; Maxfield \& Babbie, 2001; Shomker \& Wolfe, 2005).

Juvenile crime "terminology officially developed in 1899 when the first code of juvenile delinquency was enacted in Chicago, Illinois" (Shoemaker, 2005, p. 3). Similar to United States' laws, according to Turkish Criminal Code, the crimes committed by youths who is under 18 years old, are accepted as delinquent behaviors and those juveniles are called juvenile delinquents (Safak \& Safak, 2005). Juvenile crime problem has existed for centuries. However, the concern started after eighteenth and nineteenth century in Europe and America. This is a very important problem because today's delinquent will be criminal in the future (Bynum \& Thompson, 2002; Shoemaker, 2005). Although delinquency, criminals, youths and adults handled together up to nineteenth century, then it has changed. In the United States, legal system is based on free will 
and individual responsibility. For 150 years adults and juveniles are separated in Juvenile system in terms of courts and confinements facilities (Shoemaker, 2005). Turkish Criminal Code, Juvenile Protection Law and some international conventions accepted by Turkey are needed to handle delinquency separate from crime. In Turkey, all kinds of processes regarding suspect juveniles are conducted by a separate police unit of which members work in civilian cloths according to Turkish legal system (www.egm.gov.tr) It is widely accepted that juveniles are less responsible than adults. Therefore, prevention and punishment methods must be different (Shoemaker, 2005).

The issue of causality is very important to understand the reasons for delinquency. In this study, social disorganization theory will be tested for the causes of index crime incidence among Turkish juveniles. It will help to understand that whether or not this theory works for juveniles living in different societies. Index crimes that are serious crimes will be used by utilizing data from Turkey. This will be a new study about this issue. It provides a comparative study between two different societies for further researches. Due to this aim, the data collected from 205 incarcerated juveniles in Turkey were used in this study.

\section{Delinquency and Social Disorganization Theory}

Social disorganization theory is one of the most prominent delinquency theories explaining delinquency. Some of the 19th century European studies indicate a relationship between delinquency and some environmental factors such as "population density, age, sex composition, poverty, and education" (Shoemaker, 2005, p. 80). The formation of social disorganization theory and Shaw and McKay's approach is based on the study of Park and Burgess. Shaw and McKay applied concentric zone theory to juvenile delinquency (Shaw \& McKay 1942). From the ecologic perspective, they observed Chicago between 1900 and 1933. As a result of their study, in their book, "Juvenile Delinquency and Urban Areas", they explained the reasons for high level crimes in the inner cities. They examined the effects of structural variables on delinquency rates. These are low economic status, ethnic heterogeneity, and residential mobility. These structural factors cause social disorganization then social disorganization increases the crime and delinquency rates (Shaw \& McKay, 1942).

Sampson and Grove (1989) are important scholars revitalizing this theory. In their study, they mostly examine the effects of that low economic status, ethic heterogeneity, residential 
mobility and family disruption on delinquency and crime rates. As an additional structural variable, family disruption originally comes from Sampson's study. In his study, Sampson indicates the correlations among family disruption, unemployment and crime by examining Black people groups living in urban areas (Sampson, 1987).

The four major assumptions associated with this theory are: "(1) delinquency is the breakdown of institutional, community based controls, ... (2) disorganization is community based institution that is generally caused by rapid industrialization, immigration process and urbanization, ... (3) competition and dominance affect the performance of social institutions attractiveness of residential and business locations correspond closely to natural, ecological principles, ... (4) These kind of areas cause the development of criminal values and traditions" (Shoemaker, 2005; p. 82).

Cullen and Agnew (2006) also mention rapid industrialization, urbanization, breakdown of the institutions as the factors of social disorganization in their work. Intact homes, proper family values, good relationship among friends and families, and cohesive neighborhood are the most important elements of socially organized community (Williams \& McShane, 2004).

\section{Causes of Delinquency from the Perspective of Social Disorganization Theory}

Sampson and Groves (1989) measured SES by creating a summated scale including occupation, education, income, and social class when they tested social disorganization theory. When they replicated the previous study, Lowenkamp, Cullen and Travis (2003) used same variables in order to construct a SES variable. Furthermore, they used urbanization variable as one of the structural variables. In this study, I explained the socio economic status of the respondents by using their educational level, their fathers' employment status and their families' welfare status. Welfare and unemployment variables also indicated their economic status. To explain family disruption notlivingwithbothparent variable was used. There is a comparison between urban and suburban areas in Shaw and McKay's study (1942), and Sampson and Groves use urbanization as control variable. Urbanization (living in urban areas) used as a structural variable in this study as it was in Lowenkamp, Cullen and Travis's study (Lowenkamp, Cullen \& Travis; 2003). In Turkey, ethnic heterogeneity, racial and/or ethnic differences have no meaning in two points of view. The first reason is that people are officially separated as citizen or noncitizen according to Turkish Constitution. The second is that most of the people are having 
Turkish origin and there is no racial and/or ethnic thought in Turkey as it is in the US. Therefore, I did not examine ethnic heterogeneity.

As it was seen in a lot of studies, Shaw and McKay (1942), Sampson and Grove (1989), and Veysey and Messner (1999) agreed that low economic status was directly related to increase in delinquency rates. Poverty weakens the associations among the people living in the same community (Shaw \& McKay, 1942; Veysey \& Messner,1999). Many previous studies show that poverty is one of the important factors effecting crime. To Sampson, there is also direct and casual relationship between unemployment and family disruption because unemployment is a crucial reason for divorce. However, having a job, occupational status and a permanent income is a significant determinant for marital stability. The more a man earn the less likely he divorces (Sampson, 1987). To Sampson and Groves (1989), having low socio economic status communities can not establish strong and well organized structures. Moreover, in these kinds of communities participation level in voluntary organizations is very low. Thus, delinquency or crime rates increases in these communities.

Education is a one of the main factors affecting delinquency. It is accepted that there is an association between education, dropping out of school and many social problems like delinquency. Many of those children dropping out school are seen as potential delinquents due to casual linkage between dropout and delinquency. Job opportunities are quite less for less educated people because many unskilled work have been eliminated (Elliott \& Voss, 1974). About $25 \%$ of arrested Singaporean juveniles had a primary school education compared to about $65 \%$ of them had secondary school in 1999 . However, the higher level educated juveniles were less than $3 \%$ of all of them (Choi \& Lo, 2002). Education is one of the social resources affecting neighborhood positively. Thus, individuals should be encouraged to attend schools and complete their education. Education is one of the most important elements of social capital. Social capital level is high in socially organized communities where control level is also high to prevent crime. Communities having inadequate social capital are more likely to be in engaged in crime because these kinds of communities have many unemployed and undereducated individuals (Rose \& Clear, 1998).

Previous researches -especially at individual level- indicate the increasing effect of family disruption on delinquency. It is also easy to find empirical studies showing decreasing effect of it 
on social control among people because conflict and unhappiness decrease the level of participation (Sampson, 1987). As it was for other structural variables, family disruption can decrease informal social control causing social disorganization in the communities. Then, it contributes to delinquency (Sampson, 1987; Sampson \& Grove, 1989; Lowenkamp, Cullen \& Travis, 2003; Bynum \&Thompson, 2002). Many studies show the significant relationship between delinquency and broken homes because family disruption negatively affects the children (Berger, 1996; Rankin, J. H. \& Wells, L. E. 1996). To Regoli and Hewitt (2003), those studies indicate that juveniles living in single parent families are more likely than those juveniles living with their both parents to commit a crime. Due to the lower level supervision, children engage in delinquencies. They are easily influenced from different factors as well. Families are the first and crucial agent for the socialization of their children. Lack of socialization may cause the juveniles living with only one of their parents to commit a delinquent act. When juveniles from broken homes and intact homes are compared for the probability of delinquency previous studies indicate the increasing effect of broken homes on delinquency (Bynum \& Thompson, 2002).

According to Cohen and Short (1971), statistics from different countries indicates that crime and delinquency rates are higher in urban areas than rural areas. Moreover, the rates of delinquency are higher in delinquency areas. Additionally, most of serious delinquencies occur in these areas. Due to heterogeneous structure of suburban or urban areas social integration level is lower in those areas. As it is seen in Shaw and McKay's research, delinquency rates are higher in urban areas than the suburban areas. To them, neighborhood is one of the most important causes for delinquency because there is a transition from one generation to another in these neighborhoods (Shoemaker, 2005). Due to heterogeneous structure of suburban or urban areas social integration level is lower in those areas. However, neighborhoods are more homogeneous and it leads strong integration among people and decrease the delinquency rate in non criminal neighborhoods. Juveniles living in a neighborhood where criminal people live are under effect of those bad conditions. Similar to this opinion, the whole cases about non crime or non delinquency in delinquency areas can not be explained with a theory. Theoretical explanations depend on relationships. Even though residing in a delinquency area will increase the likelihood of committing crime, some factors such as family, school, and peer relationships can decrease the probability of delinquency. These factors provide more control on juveniles (Shoemaker, 2005). Social control level is low in urban areas or in other words social control is very weak among the 
individuals living those areas. Thereby, urbanization decrease the level of solidarity among the people and this situation causes social disorganization (Sampson and Groves, 1989). Lowenkamp, Cullen and Travis (2003) agreed the increasing effect of urbanization on crime in their study. According to FBI's uniform crime report, the highest arrests for juveniles were in the large cities in 1998. The lowest arrests were in rural counties. However, arrests were two fold more than in suburban countries in the same year in terms of total crime index. The larger cities have the higher arrest rates. For instance, cities having more than 250,000 people had an arrest rate of about $8 \%$ per 100,000 residents compared to smaller cities having less than 50,000 people had a rate of about $5 \%$ in 1995. It is obviously seen that juveniles living in urban areas are more likely to commit a crime. They are also more likely than their rural counterparts to commit more serious crimes (Bynum \& Thompson, 2002).

In sum, this study examines the causes of index crimes from the perspective of social disorganization theory by utilizing data from Turkey. Education, welfare, unemployment, urbanization, and family disruption variables used to be examined as the causes for crimes among Turkish incarcerated juveniles. No variable used about ethnic heterogeneity due the above mentioned characteristic of Turkey.

\section{Hypotheses}

The following five hypotheses were proposed for this study based on the previous studies about this issue.

Hypothesis 1: Juveniles having some high school or higher education is less likely than juveniles having $8^{\text {th }}$ grade or less education to commit at least one index crime.

Hypothesis 2: Juveniles whose families were on welfare when they were growing up are more likely than those juveniles whose families were not on welfare when they were growing up to commit at least one index crime.

Hypothesis 3: Juveniles whose fathers were employed when they were growing up are less likely than those juveniles whose father were unemployed when they were growing up to commit at least one index crime. 
Hypothesis 4: Juveniles living in urban areas while they were growing up are more likely than those juveniles living in rural areas while they were growing up to commit at least one index crime.

Hypothesis 5: Juveniles growing up with both of their natural parent living at home are less likely than those juveniles who did not grow up with both of their natural parent living at home to commit at least one index crime.

\section{Data and Methods}

\section{Data}

The data (Gunes, 2007) were collected from two sources. The first sample is from 205 incarcerated juveniles at different juvenile correction facilities in Turkey and the second sample is from the 200 college students in Turkey. However, after restriction, only the first sample will be used to test the proposed hypotheses. During restriction, one of the two categories of status variable, incarcerated was selected.

The data are cross- sectional and individual level data because they were collected between January 2007 and March 2007 from the respondents incarcerated in eight different juvenile correction facilities in Turkey. The locations of those facilities and the number of respondents were indicated in the following table:

\section{Location of Correction Facilities Number of Respondents}

\begin{tabular}{ll}
\hline Ankara & 30 \\
Bursa & 30 \\
Diyarbakir & 30 \\
İstanbul & 60 \\
İzmir & 10 \\
Malatya & 10 \\
Mersin & 25 \\
Samsun & 10
\end{tabular}

As of December 2006 total number of the incarcerated juveniles was 2016 in these facilities (Gunes, 2007). 
The survey was conducted by Gunes (2007) and administrated by the social workers in the juvenile correction facilities. Besides the survey, the data include the incarcerated juveniles' records which were used in the analysis. Due to the fact that the sample for the incarcerated respondents was selected by the administrators and the social workers of each juvenile detention center, this is a non-probability convenience sample. The data collection process was done with the permission of the Turkish Ministry of Justice because it is not possible to conduct a research without the approval of Ministry of Justice in any prison throughout Turkey. The restricted sample contains 205 cases; however, before conducting analysis I applied listwise deletion so that all of the analyses were based on the same cases. After deletion of the missing values, 148 cases remain for the analyses.

The data set has an advantage to understand the some effecting factors on index crime incidence among juveniles in Turkey, because there is no enough information about this issue in the United States. Additionally, sample size is large enough to understand the topic when we compare it to actual population size. Even though non-probability convenience sampling technique prevents to generalize the finding to the population, the data are adequate data available to explain the issue.

\section{Methods}

Firstly descriptive analyses were used to indicate the central tendencies and standard deviations of the variables used in the analysis. Then, due to the fact that dependent variable index crime incidence is a nominal and dichotomous variable, binary logistic regression was used to analyze the effects of the explanatory variables on the probability of index crime incidence. As a statistical analysis technique, binary logistic regression is used to see the effects of one or more predictors on a dichotomous predicted variable (Foster, Barkus \& Yavorsky, 2006). One of the three methods for including variables, simultaneous (standard) method, was used in the analysis. According to this method, all independent variables are included at the same time. SPSS 15.0 for windows was used for the analysis.

\section{Measures}

Binary logistic regression analysis requires a dichotomous dependent variable. Dichotomous or metric (interval/ratio) variables are the best variables for the analyses. During the analyses only dichotomous variables were used. 
In this study, index crime incidence used as the dependent variable that contains the following crimes (Gunes, 2007):

1) Taken a car for a ride without the owner's permission.

2) Broken into and entered a home, building, or store.

3) Used a weapon in a fight with another person.

4) Taken something valued at more than 20TL (about \$9.5) but less than 700TL (about $\$ 333)$.

5) Taken something of larger value (more than $\$ 750$ ).

6) Used force or a weapon to take money or something of value from another person.

The dependent variable, index crime incidence is a nominal and dichotomous variable. The categories of index crime incidence are $1=$ juveniles committed at least one index crime and 0 (not committed an index crime).

Education was three point scale ordinal variable in the data. The categories of education were $8^{\text {th }}$ grade or less, some high school education, and high school graduate. I dummy coded education variable as $1=$ some high school education or higher and $0=8^{\text {th }}$ grade or less.

Welfare is a dummy coded nominal variable $(1=$ Juveniles whose families were on welfare when they were growing, and $0=$ juveniles whose families were not on welfare when they were growing up.

Social class variable were dummy coded as $0=$ juveniles having an employed father $1=$ juveniles having an unemployed father. I named the new variable as unemployment.

Live with variable was a dummy coded nominal variable. I changed its name as notlivingwithbothparent. It has the following categories; $1=$ juveniles who did not grow up with both of their natural parent living at home and $0=$ Juveniles grew up with both of their natural parent living at home.

I created urban dummy coded variable by using community variable. The categories of urban variable are $1=$ juveniles living in urban areas while they were growing up and $0=$ juveniles living in rural areas while they were growing up. 


\section{Assumptions and Data Screening}

According to Hosmer and Lemeshow's guideline, the minimum number of cases per independent variable should be 10 for binary logistic regression analysis. I have 5 independent variables for the analysis and my sample employed listwise deletion is 148 that is more than 50 $(10 \mathrm{k} \rightarrow 10 \mathrm{x} 5=50)$. Therefore, sample size is enough to run binary logistic regression.

I checked outliers by using the following criteria. If standardized residuals are not between -2.58 and +2.58 , it is problematic. No outlier was found in the analyses according to the criteria because the standardized residuals values were between -1.68 and +1.88 .

Logistic regression does not make any assumptions of normality, linearity, and homogeneity of variance for the independent variables. However, multicollinearity, cells with zero expected count, and complete separation are the problems for logistic regression.

To detected numerical problems such as multicollinearity among independent variables, cells with low expected counts, and complete separation, I used the criteria of standard errors larger than 2 meant problematic. However, all of the standard errors for the $\mathrm{b}$ coefficients were less than 2 in multivariate analyses (SEs: education $=.428$, welfare $=.413$, unemployment $=$ .493 , urban $=.437$, and notlivingwithbothparent $=.635$ ). In order to detect multicollinearity problem, I also used Paul Allison's guidelines for variance of influence factor (VIF) by running linear regression. According to his criterion VIF $\geq 2.5$ is problematic. All VIF values were only slightly greater than 1 (VIFs: education $=1.080$, welfare $=1.211$, unemployment $=1.108$, urban $=$ 1.035 , and notlivingwithbothparent $=1.021$ ). Thus, there is no multicollinearity problem among the variables.

Directional hypotheses and one tailed test were used in the analyses. Even though sample size was adequate to test the proposed hypotheses it was not very large $(\mathrm{N}=148)$. Thus, 0.1 value was used as the alpha level in order to indicate significance level as it was recommended in Warner's work (Warner, 2008).

\section{Results}

\section{Descriptive Analyses}

Table 1 presents the central tendencies of the variables used in the analysis. Even though mode is the best central tendency for nominal variable I also put the means of the variables to 
explain them with percentage because it is possible to interpret dichotomous variables by using the means.

Table 1 indicates that in 2007, majority $(60 \%)$ of the incarcerated juveniles committed at least one of the index crimes. Only about one fourth (24\%) of them had some college or higher education. Even though about $34 \%$ of the incarcerated juveniles' families were on welfare only about $16 \%$ of the juveniles had unemployed fathers. More than three fourth $(78 \%)$ of the respondents lived in urban areas and only $13 \%$ of them did not live with both of their natural parents when they were growing up.

Table 1. Descriptive Statistics for the Variables Used in the Analysis, Turkey. Juveniles, 2007.

\begin{tabular}{|c|c|c|}
\hline Variable & Mode & Mean \\
\hline $\begin{array}{l}\text { Dependent Variable } \\
\text { Index crime incidence }\end{array}$ & $\begin{array}{l}1 \text { (committed at least } \\
\text { one index crime) }\end{array}$ & .60 \\
\hline $\begin{array}{l}\text { Independent Variables } \\
\text { Education } \\
(1=\text { some high school or } \\
\text { higher })\end{array}$ & $1\left(8^{\text {th }}\right.$ grade or less $)$ & .24 \\
\hline $\begin{array}{l}\text { Welfare } \\
(1=\text { on welfare })\end{array}$ & 0 (not on welfare) & .34 \\
\hline $\begin{array}{l}\text { Unemployment } \\
\text { (1= unemployed father) }\end{array}$ & 0 (having employed father) & .16 \\
\hline $\begin{array}{l}\text { Urban } \\
\text { (1= living in urban) }\end{array}$ & 1 (lived in urban) & .78 \\
\hline $\begin{array}{l}\text { Notlivingwithbothparent } \\
\text { (1= not living with both parent) }\end{array}$ & 0 (lived with both parent) & .13 \\
\hline
\end{tabular}

\section{Multivariate Analyses}

To determine the effects of the explanatory variables on the probability of index crime incidence among Turkish Juveniles, binary logistic regression was employed. 
Table 2 indicates the logistic regression results predicting the effecting factors on the probability of index crime incidence among Turkish Juveniles in 2007. Due to Model $\chi^{2}(=15.968)$ is significant at $\mathrm{p}<.01$ level, it is said that this is a good model because this model fits better than a model having only the intercept term does (Nagelkerke Pseudo $\mathrm{R}^{2}=.138$, Cox-Snell Pseudo- $\mathrm{R}^{2}=$ $.107)$.

As it was expected and hypothesized education has a significant effect on the probability of index crime incidence and juveniles having some high school or higher education is less likely than juveniles having $8^{\text {th }}$ grade or less education to commit at least one index crime $(B=-1.145$ and $\mathrm{p}<.01)$. The odds ratio value of .318 indicates that Turkish incarcerated juveniles having some high school or higher education are about $68 \%$ less likely than those incarcerated juveniles having $8^{\text {th }}$ grade or less education to commit an index crime $(.318-1=.682)$.

Surprisingly, welfare (juveniles whose families were on welfare when they were growing up) has no significant effect on the likelihood of index crime incidence holding for other variables constant in the model. However, it was expected that juveniles whose families were on welfare when they were growing up are more likely than those juveniles whose families were not on welfare when they were growing up to commit at least one index crime. Due to this result, research hypothesis is rejected.

Similar to welfare, unemployment (Juveniles whose fathers were unemployed when they were growing up) has no significant effect on the probability of index crime incidence controlling for other variables in the model. Nevertheless, many studies indicate a relationship between unemployment and crime, having an unemployed father does not affect the probability of delinquency in this analysis. Thereby, this result does not support the proposed hypothesis that juveniles whose fathers were employed when they were growing up are less likely than those juveniles whose father were unemployed when they were growing up to commit at least one index crime.

Urban (living in urban areas while growing up) also has a significant effect on the probability of index crime incidence. This relationship supports the proposed hypothesis that the incarcerated juveniles who lived in urban areas are more likely to commit an index crime than those who did not live in urban areas $(B=1.091$ and $\mathrm{p}<.05)$. The odds ratio for urban is 2.978 indicates that incarcerated juveniles who lived in urban areas while they were growing up, are 
about $198 \%$ more likely than those incarcerated juveniles living in rural areas while they were growing up to commit an index crime $(2.978-1=1.978)$.

The last variable having significant effect on the likelihood of index crime incidence was family disruption variable (notlivingwithbothparent). As it was expected juveniles growing up with both of their natural parent living at home are less likely than those juveniles who did not grow up with both of their natural parent living at home to commit at least one index crime $(B=$ 1.217 and $\mathrm{p}<0.1$ ). Specifically, incarcerated juveniles who did not grow up with both of their natural parents are about $238 \%$ more likely than the incarcerated juveniles growing up with both of their natural parents to commit at least one index crime (Odds ratio $=3.376 \rightarrow 3.376-1=$ 2.376). The result is consistent with my hypothesis.

Table 2. Logistic Regression Results Predicting the Effecting Factors on the Probability of Index Crime Incidence, Turkey, Juveniles, 2007 ( $\mathrm{N}=148)$

\begin{tabular}{|c|c|c|c|c|c|c|c|}
\hline \multirow[t]{2}{*}{ Predictor } & \multirow{2}{*}{\multicolumn{2}{|c|}{ Logit (B) (SE Logit) }} & \multirow[t]{2}{*}{ Wald $\mathrm{P}$} & \multirow[t]{2}{*}{ P-Value } & Odds & \multicolumn{2}{|c|}{$\underline{90 \% \mathrm{CI}^{\mathrm{a}}}$} \\
\hline & & & & & Ratio & Lower & Upper \\
\hline $\begin{array}{l}\text { Education } \\
\text { (1=some high school or } \\
\text { higher) }\end{array}$ & $-1.145 * * *$ & .428 & 7.153 & .007 & .318 & .157 & .644 \\
\hline $\begin{array}{l}\text { Welfare } \\
(1=\text { on welfare })\end{array}$ & -.300 & .413 & .526 & .468 & .741 & .376 & 1.462 \\
\hline $\begin{array}{l}\text { Unemployment } \\
\text { (1= unemployed father) }\end{array}$ & -.325 & .493 & .434 & .510 & .722 & .321 & 1.626 \\
\hline $\begin{array}{l}\text { Urban } \\
\text { (1= living in urban) }\end{array}$ & $1.091 * *$ & .437 & 6.226 & .013 & 2.978 & 1.451 & 6.115 \\
\hline $\begin{array}{l}\text { Notlivingwithbothparent } \\
\text { (1= not living with both } \\
\text { parent) }\end{array}$ & $1.217^{*}$ & .635 & 3.671 & .055 & 3.376 & 1.188 & 9.595 \\
\hline Constant & -.123 & .435 & .080 & .777 & .884 & & \\
\hline $\begin{array}{l}\text { Model } \chi^{2} \\
\text { Degrees of freedom } \\
\text { P- Value } \\
\text { Cox-Snell Pseudo-R }{ }^{2} \\
\text { Nagelkerke Pseudo-R }{ }^{2}\end{array}$ & $\begin{array}{l}16.819 \\
5 \\
<.01 \\
.107 \\
.145 \\
\end{array}$ & & & & & & \\
\hline
\end{tabular}

${ }^{*} \mathrm{p}<0.1, * * \mathrm{p}<0.05, * * * \mathrm{p}<0.01$ (One-Tailed Test) ${ }^{\mathrm{a}} 90 \%$ confidence interval for odds ratio. 


\section{Conclusion}

Juvenile delinquency is still a crucial problem for every society because today's delinquents will be the tomorrow's criminals. Even today, they threaten the security and welfare of the societies. Thus, this problem has to be solved or at least to be eliminated as soon as possible. Furthermore, only by understanding the causes of delinquency can appropriate solution ways find. In this study, I tried to find the effects of five different factors on index crime incidence by utilizing data belonging to 205 Turkish incarcerated juveniles. These factors were selected based on social disorganization theory that is one of the major theories explaining crime and delinquency.

As it was expected the more educated juveniles the less likely to commit index crimes. Thereby, governments have to focus on education; however, education has to have appropriate content as it was said by a lot of researchers. That is, education must include appropriate items for preventing delinquency. Education, as a crucial component of social capital, is very important to provide a socially organized community in which crime and delinquency rates are low.

Even though previous studies showed that economic situation and unemployment have increasing effects on the probability of index crime incidence, I could not find any statistically significant difference. The reason for these results may be because of the sampling technique that is non probability convenience sampling technique.

Family disruption indicated increasing effect on the likelihood of index crime incidence in this study. Family is the core of the society. It is the first school of the children. It is the starting point of the life in this world for them. Lower level supervision decreases the level of socialization. Furthermore, broken homes make the children unhappy and this situation causes engagement in delinquencies.

The result relationship between living in urban areas and index crime incidence supported the proposed hypothesis and previous studies. A lot of studies, statistics, and uniform crime reports indicated the effect of living in an urban area on the probability of delinquency.

Because of a lot of factors such as population density and weak social integration, juveniles living in urban areas are more likely to commit index crime. In today's world, the population living in urban areas is increasing. Therefore, it is needed to look for and find new solution methods for reducing the delinquent rates. 
The data used in the analyses were not collected for the purpose of testing social disorganization theory. Therefore it was not possible to test residential mobility. There was a variable measuring residential mobility; however, after I employed listwise deletion one of the categories of that dummy dichotomous variable has only one case that would be problematic for the regression analysis. As it was mentioned in the study to use a variable showing racial/ethnic heterogeneity was not possible because there was no such differentiation among the Turkish citizens in Turkey. Nevertheless this variable may only be used in the studies used data from the metropolitan counties having foreign people. Besides these, using non probability convenience sampling may have affected the results.

Although these limitations, all of the factors examined in this study were the causing and increasing factors of juvenile delinquency according to social disorganization theory. The sample size was adequate to run binary logistic regression and it was more than one fourteenth of the whole population in those incarcerated correction facilities. I believe that this study will help to understand causes for delinquency in a different society from the perspective of this theory. Moreover, it is also possible to improve this study by collecting data using probability sampling technique for this purpose and for future researches.

\section{References}

Bartollas, C. (2006). Juvenile delinquency. Boston: Pearson Education.

Berger, R. J. (Ed.) (1996). The sociology of juvenile delinquency. Chicago: Nelson-Hall.

Bynum, J. E., \& Thompson, W. E. (2002). Juvenile delinquency. Boston: Pearson Education.

Cohen, A. K. \& Short, J. F. Jr. (1971). Crime and juvenile delinquency. In R. K., Merton \& R., Nisbet (Eds), Contemporary social problems (pp. 89-146). New York: Harcourt Brace Jovanovich.

Choi, A., \& Lo, T. W. (2002). Fighting youth crime. Singapore: Times Academic Press.

Cullen, F. T., \& Agnew, R. (2006). Criminological theory. Los Angeles: Roxbury Publishing.

Elliott, D. S., \& Voss, H. L. (1974). Delinquency and dropout. Lexington: D.C. Heat and Company.

Foster, J., Barkus, E., \& Yavorsky, C. (2006). Understanding and using advanced statistics. Londan: Sage Publications.

Gunes, I. D. (2007). Deviant behavior among young adults: Turkish case with an emphasis on family rituals, self-esteem, and religiosity. Unpublished manuscript, University of North Texas. 
Lowenkamp, C.T., Cullen, F.T., \& Pratt, T.C. (2003). Replicating Sampson and Groves's test of social disorganization theory: Revisiting a criminological classic. Journal of Research in Crime and Delinquency, 40(4), 351-373.

Maxfield, M. G., \& Babbie, E. (2001). Research methods for criminal justice and criminology. Belmont: Wadsworth/Thomson Learning.

Rankin, J. H. \& Wells, L. E. (1996). The preventive effects of the family on delinquency. In R. J., Berger (Ed.), The sociology of juvenile delinquency (pp. 201-217).

Chicago: Nelson-Hall. Rose, D. A. \& Clear, T. R. (1998). Incarceration, social capital, and crime: Implications for social disorganization theory. Criminology. 36(3), 441-479.

Regoli, R. M. \& Hewitt, J. D. (2003). Delinquency in society. New York: McGraw-Hill.

Safak, A., \& Safak, A. S. (2005). Guvenlik kuvvetleri ve polis mevzuati. Ankara.

Sampson, R. J., \& Groves, W. B. (1987). Urban black violence: The effect of male joblessness and family disruption. The American Journal of Sociology. 93(2), 348-382.

Sampson, R. J., \& Groves, W. B. (1989). Community structure and crime: Testing social disorganization theory. The American Journal of Sociology. 94(4):774-802.

Shaw, C. R. \& McKay, H. D. (1942). Juvenile delinquency in urban areas. Chicago: University of Chicago Press.

Shoemaker, D. J. (2005). Theories of delinquency. New York: Oxford University Press.

Shoemaker, D. J., \& Wolfe, T. W. (2005). Juvenile justice. Santa Barbara: ABC-CLIO.

Veysey, B. M., \& Messner, S. F. (1999). Further testing of social disorganization theory:

An elaboration of Sampson and Groves's "Community Structure and Crime". Journal of Research in Crime and Delinquency, 36(2), 156- 174.

Warner, R.M. (2008). Applied statistics. From bivariate through multivariate techniques. Los Angeles: Sage Publications.

Williams, F. P., \& McShane, M. D. (2004). Criminological theory. Upper Saddle River: Pearson Education. 